\title{
Potensi antimikroba minyak atsiri daun jeruk (Citrus)
}

\author{
Antimicrobial potential of orange leaf essential oil \\ (Citrus)
}

Munira $^{1}$

\begin{abstract}
Background: Some plants that are included in the genus Citrus are one of the plants producing essential oils which is a natural substance that is known to have an antibacterial effect.

Objectives: The study aims to determine the ability of essential oils from the leaves of several types of citrus (Citrus) in inhibiting the growth of Escherichia coli.

Methods: An experimental study using a complete randomized design consisting of 4 treatments and four replications each. The treatments consisted of distilled water (control), lime leaf essential oil, kaffir lime essential oil and lime leaf essential oil. Microbiology test uses agar diffusion method.

Results: Anova test showed that essential oils from some lime can inhibit the growth of Escherichia coli $(p=0.000)$. Duncan's further test results showed that the average diameter of the inhibition zone formed showed that the average diameter of the largest inhibition zone was formed in the treatment which was given lime orange essential oil (16.55 $\mathrm{mm})$ and was not significantly different $(p<0.05)$ with orange essential oil kaffir $(15.40 \mathrm{~mm})$ and lime essential oil $(14.97$ $\mathrm{mm}$ ). Based on the Duncan test results showed that there is no difference in the average diameter of inhibitory zones between essential oils of lime, lime and lime, this can be caused because the three lime are classified in the same genus, namely the genus citrus.

Conclusion: Essential oils from some lime can inhibit the growth of Escherichia coli. The average diameter of the inhibition zone that formed showed the greatest inhibition formed in the treatment which was given lime essential oil.
\end{abstract}

\section{Keywords}

Citrus, essential oils, Escherichia coli

\begin{abstract}
Abstrak
Latar Belakang: Beberapa tanaman yang termasuk dalam genus citrus merupakan salah satu tanaman penghasil minyak atsiri yang merupakan suatu substansi alami yang dikenal memiliki efek antibakteri.

Tujuan: Penelitian bertujuan untuk mengetahui kemampuan minyak atsiri dari daun beberapa jenis jeruk (Citrus) dalam menghambat pertumbuhan Escherichia coli.

Metode: Penelitian eksperimental dengan menggunakan rancangan acak lengkap yang terdiri dari 4 perlakuan dan masing-masing empat ulangan. Perlakuan terdiri dari aquades (kontrol), minyak atsiri daun jeruk nipis, minyak atsiri daun jeruk purut dan minyak atsiri daun jeruk limau. Uji mikrobiologi menggunakan metode difusi agar.

Hasil: Uji Anova menunjukkan bahwa minyak atsiri dari beberapa jeruk nipis dapat menghambat pertumbuhan Escherichia coli $(p=0.000)$. Hasil uji lanjut Duncan menunjukkan bahwa Rata-rata diameter zona hambat yang terbentuk menunjukkan bahwa rata-rata diameter zona hambat paling besar terbentuk pada perlakuan yang diberi minyak atsiri jeruk limau $(16.55 \mathrm{~mm})$ dan tidak berbeda nyata $(\mathrm{p}<0.05)$ dengan minyak atsiri jeruk purut $(15.40$ $\mathrm{mm}$ ) dan minyak atsiri jeruk nipis $(14.97 \mathrm{~mm})$. Berdasarkan hasil uji Duncan menunjukkan bahwa tidak terdapat perbedaan rata-rata diameter zona hambat antara minyak atsiri daun jeruk nipis, jeruk purut dan jeruk limau, hal ini dapat disebabkan karena ketiga jeruk nipis tersebut tergolong dalam genus yang sama yaitu genus citrus.
\end{abstract}

\footnotetext{
${ }^{1}$ Jurusan Farmasi Politeknik Kesehatan Kemenkes Aceh. E-mail: munira.ac@gmail.com 
Kesimpulan: Minyak atsiri dari beberapa jeruk nipis dapat menghambat pertumbuhan Escherichia coli. Rata-rata diameter zona hambat yang terbentuk menunjukkan hambat paling besar terbentuk pada perlakuan yang diberi minyak atsiri jeruk limau.

\section{Kata Kunci}

Citrus, minyak atsiri, Escherichia coli

\section{Pendahuluan}

ndonesia kaya akan sumber daya alam yang berpotensi untuk digunakan dalam pengobatan. Bukti-bukti tentang khasiat tanaman obat sudah banyak ditemukan sejak ratusan tahun yang lalu oleh nenek moyang kita. Mereka memanfaatkan tanaman obat tradisional sebagai upaya penyembuhan kesehatan, jauh sebelum obatobatan modern yang sekarang ada (Widharto, 2019). Obat tradisional telah banyak memberi pengaruh yang jelas terhadap tubuh secara keseluruhan. Selain harganya yang murah dan mudah di dapat, obat tradisional juga memiliki efek samping yang jauh lebih rendah tingkat bahayanya dibanding dengan bahan obat-obatan kimia (Marsono, 2008).

Tanaman berkhasiat sebagai obat telah banyak dipelajari secara ilmiah yang hasilnya membuktikan bahwa tanaman tersebut memiliki kandungan kimia yang bermanfaat bagi kesehatan manusia. Salah satu dari sekian banyak tanaman berkhasiat obat tersebut adalah tanaman yang termasuk dalam famili rutaceae. Rutaceae merupakan salah satu famili tanaman yang terdiri dari 130 genus yang terdapat di dalam tujuh subfamili (Grafton-Cardwell et al., 2013). Genus dari tanaman yang termasuk dalam famili rutaceae di antaranya adalah citrus, microcitrus, fortunella, poncirus, cymenia, dan eremocitrus. Di antara enam genera ini yang paling banyak dikenal adalah dari genus citrus (Hertiani et al., 2003).

Beberapa tanaman yang termasuk dalam genus citrus antara lain jeruk nipis (Citrus aurantifolia (Christm.) Swingle), jeruk purut (Citrus hystrix DC.), jeruk lemon (Citrus lemon (L.) Burm. f.), jeruk bali (Citrus maxima (Burm.f.) Merr.) dan jeruk limau (Citrus amblycarpa Ochse \& De Vries). Tanaman genus citrus merupakan salah satu tanaman penghasil minyak atsiri yang merupakan suatu substansi alami yang dikenal memiliki efek antibakteri (Chutia et al., 2009).

Minyak atsiri merupakan senyawa yang pada umumnya berwujud cairan, yang diperoleh dari bagian tanaman, akar, kulit, batang, daun, buah, biji maupun dari bunga dengan cara penyulingan (Fadlilah, 2015). Aktivitas antibakteri minyak atsiri disebabkan karena minyak atsiri mengadung senyawa yang dapat menghambat atau membunuh pertumbuhan bateri (Kan et al., 2006).

Mikroba merupakan penyebab penyakit pada umumnya yang lebh dikenal sebagi faktor penyakit infeksi. Penyakit ini dapat disebabkan oleh beberapa mikroorganisme seperti bakteri, virus, parasit, dan jamur (Jawetz et al., 2005). Di antara bakteri yang dapat menyebabkan infeksi adalah Escherichia coli. Escherichia coli dapat menyebabkan infeksi saluran kemih, diare, sepsis dan meningitis (Grafton-Cardwell et al., 2013). Sampai saat ini telah banyak penelitian yang dilakukan terkait dengan penggunaan minyak atsiri dari jeruk baik sebagai antimikroba. Bagian dari jeruk yang dapat menghasilkan minyak atsiri adalah buah dan daun. Salah satu penelitian yang dilakukan Yuliani et al. (2011), membuktikan bahwa minyak atsiri dari daun jeruk purut memiliki aktivitas antibakteri terhadap S. aureus dan E. coli. Begitu juga hasil penelitian Kharismayanti (2015) yang menyatakan bahwa minyak atsiri dari daun jeruk nipis dapat menghambat bakteri Phorphyromonas gingivalis.

Mengingat sampai sejauh ini belum ada informasi tentang penggunaan minyak atsiri dari daun jeruk nipis, jeruk purut dan jeruk limau untuk menghambat pertumbuhan bakteri $E$. coli. Oleh sebab itu perlu dilakukan penelitian tentang potensi minyak atsiri dari daun jeruk untuk menghambat pertumbuhan bakteri. Tujuan penelitian ini adalah untuk mengetahui kemampuan minyak atsiri dari daun beberapa jenis jeruk (Citrus) dalam menghambat pertumbuhan Escherichia coli.

\section{Metode}

Jenis penelitian merupakan bersifat eksperimental laboratorium. Penelitian ini dilaksanakan pada bulan Mei sampai September 2017 di Laboratorium Pertanian Universitas Syiah Kuala Banda Aceh untuk melakukan proses destilasi dan untuk uji 
mikrobiologi dilakukan di Laboratorium Mikrobiologi Jurusan Farmasi Poltekkes Kemenkes Aceh.

Alat yang digunakan adalah timbangan analitik, alat destilasi, beaker glass, gelas ukur, labu Erlenmeyer, pipet ukur, cawan petri, tabung reaksi, spatula, batang pengaduk, hot plate, lampu Bunsen, ose, batang bengkok, pipet tetes, pinset, autoklaf, inkubator dan mistar. Bahan yang digunakan dalam penelitian ini adalah daun jeruk nipis, daun jeruk purut dan daun jeruk limau yang akan diperoleh dari kawasan Aceh Besar, aquadest, $\mathrm{NaCl} 0.9 \%$, asam sulfat $1 \%$, barium klorida $1 \%$, bakteri Escherichia coli yang diperoleh dari Fakultas Kedokteran Hewan, media Nutrien Agar (NA), kapas, cakram, kertas pembungkus, kapas, korek api, masker, sarung tangan, dan kertas label.

\section{Penyiapan Simplisia}

1. Masing-masing daun jeruk (jeruk nipis, jeruk purut, jeruk limau) dipetik dari pohonnya.

2. Kemudian dicuci dengan air mengalir selanjutnya dikering anginkan lalu dipotongpotong untuk dilakukan destilasi.

Destilasi Minyak Atsiri. Destilasi akan dilakukan menurut prosedur (Armando, 2009):

1. Daun jeruk segar yang sudah dicuci lalu dikering anginkan dan selanjutnya dipotong-potong lalu dimasukkan ke dalam bejana destilasi yang sebelumnya sudah diisi air lalu dipanaskan sampai mendidih.

2. Selanjutnya uap air bersama komponen minyak ditampung dalam wadah yang tertutup.

3. Minyak atsiri yang diperoleh dari penyulingan ke dalam corong pemisah untuk memisahkan minyak atsiri dengan air, penyulingan dilakukan sampai tetesan minyak atsiri pada penampung sudah tidak menetes lagi (5 jam penyulingan).

4. Hasil penyulingan dipisahkan dari air dengan menambahkan Na sulfat anhidrat.

5. Minyak atsiri yang diperoleh lalu disimpan dalam botol yang tertertutup rapat dan terlindung dari cahaya.

Pembuatan Media NA

1. Serbuk media NA ditimbang sebanyak 10 gram dan dimasukkan ke dalam erlenmeyer.

2. Ditambahkan aquadest sebanyak $500 \mathrm{~mL}$ dan dipanaskan sampai larut.

3. Kemudian disterilkan di dalam autoklaf pada suhu $121^{\circ} \mathrm{C}$ selama 15 menit.
Pembuatan Suspensi Bakteri

1. Masing-masing biakan koloni E. Coli yang berumur 24 jam diambil dengan ose bulat steril.

2. Kemudian masing-masing disuspensikan ke dalam tabung reaksi yang berisi $10 \mathrm{~mL} \mathrm{NaCl} 0.9 \%$ dan dikocok hingga terbentuk kekeruhan yang setara dengan standar $0.5 \mathrm{Mc}$. Farland

Uji Mikrobiologi

1. Disiapkan petridish sebanyak 4 buah. Masingmasing dituangkan media NA sebanyak $15-20$ $\mathrm{mL}$. Setiap petri dish dibagi menjadi 4 daerah (4 perlakuan) dengan menggunakan spidol.

2. Masing-masing suspensi bakteri E. coli diinokulasikan sebanyak $0.1 \mathrm{~mL}$ di atas permukaan media NA, lalu diratakan dengan menggunakan batang bengkok.

3. Cakram yang sudah steril direndam dalam masing-masing perlakuan. Masing-masing kertas cakram ditempelkan di atas permukaan media.

4. Semua petridish yang telah diinokulasi $E$. coli diinkubasi pada suhu $37^{\circ} \mathrm{C}$ selama $2 \times 24$ jam.

5. Diukur masing-masing diameter zona hambat yang terbentuk dengan menggunakan mistar.

Penelitian ini menggunakan Rancangan Acak Lengkap (RAL) yang terdiri dari 4 perlakuan dan masing-masing 4 ulangan. Parameter yang diamati dalam penelitian ini adalah diameter zona hambat. Data yang telah diperoleh yaitu berupa diameter zona hambat selanjutnya dilakukan analisis data dengan menggunakan uji Anova dan dilanjutkan dengan uji Duncan pada taraf signifikan $99 \%$ atau $\alpha=0.01$.

\section{Hasil}

Berdasarkan hasil uji mikrobiologi minyak atsiri dari beberapa daun jeruk diperoleh hasil bahwa minyak atsiri dari jeruk nipis, jeruk purut dan jeruk limau dapat menghambat pertumbuhan Escherichia coli. Hal ini ditandai dengan terbentuknya zona hambat di sekitar cakram.

Rata-rata diameter zona hambat dari minyak atsiri jeruk nipis adalah $14.97 \mathrm{~mm}$, jeruk purut sebesar $15.40 \mathrm{~mm}$ dan jeruk limau adalah $16.55 \mathrm{~mm}$. Setelah dilakukan uji statistik menggunakan Anova terhadap rata-rata diameter zona hambat diperoleh hasil seperti yang tertera pada tabel 1. 
Tabel 1. Hasil uji anova rata-rata diameter zona hambat minyak atsiri daun dari beberapa jenis jeruk terhadap pertumbuhan escherichia coli

\begin{tabular}{lccc}
\hline Perlakuan & $\begin{array}{c}\text { Rata-rata } \\
(\mathrm{mm})\end{array}$ & $\begin{array}{c}\text { Standar } \\
\text { Deviasi } \\
(\mathrm{mm})\end{array}$ & Nilai p \\
\hline Aquadest & 0.00 & 0.00 & 0.000 \\
Jeruk nipis & 14.97 & 2.53 & \\
Jeruk purut & 15.40 & 1.68 & \\
Jeruk limau & 16.55 & 2.00 & \\
\hline
\end{tabular}

Berdasarkan hasil penelitian (tabel 1) dapat dilihat bahwa minyak atsiri daun dari beberapa jenis jeruk dapat menghambat pertumbuhan Escherichia coli $(p=0.000)$. Setelah dilakukan uji lanjut dengan menggunakan uji Duncan diperoleh hasil bahwa rata-rata diameter zona hambat yang terbentuk menunjukkan bahwa rata-rata diameter zona hambat paling besar terbentuk pada perlakuan yang diberi minyak atsiri jeruk limau $(16.55 \mathrm{~mm})$ dan tidak berbeda nyata $(p<0.01)$ dengan minyak atsiri jeruk purut $(15.40 \mathrm{~mm})$ dan minyak atsiri jeruk nipis (14.97 mm).

Berdasarkan hasil uji anova diperoleh hasil bahwa minyak atsiri dari daun jeruk sangat signifikan dalam menghambat pertumbuhan Escherichia coli $(P=0,000)$. Hal ini disebabkan kandungan senyawa kimia yang berperan sebagai antimikroba yang terdapat dalam minyak atsiri daun jeruk.

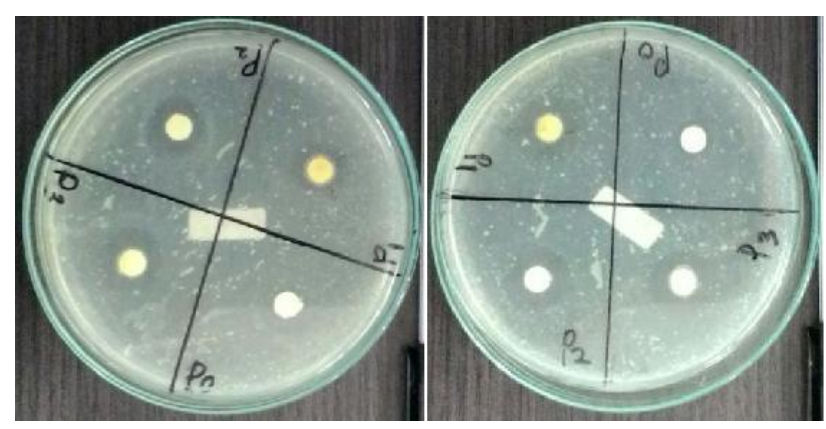

Gambar 1. Diameter zona hambat dalam minyak atsiri daun jeruk terhadap pertumbuhan escherichia coli

Hasil uji lanjut yaitu menggunakan uji Duncan sebagaimana disajikan pada tabel 2, dapat dilihat bahwa rata-rata diameter zona hambat yang diperoleh berada antara $14.97 \mathrm{~mm}$ sampai dengan $16.55 \mathrm{~mm}$, dan bila dikategorikan ke dalam kemampuannya sebgai daya hambat, maka ketiga minyak atsiri daun jeruk tersebut memiliki daya hambat dengan kategori kuat.
Tabel 2. hasil uji lanjut rata-rata diameter zona minyak atsiri daun dari beberapa jenis jeruk terhadap pertumbuhan escherichia coli

\begin{tabular}{lcc}
\hline Perlakuan & $\begin{array}{c}\text { Rata-rata Diameter } \\
\text { Zona Hambat }(\mathrm{mm}) \\
\pm \text { Standar Deviasi }\end{array}$ & $\begin{array}{c}\text { Kategori } \\
\text { Daya } \\
\text { Hambat }\end{array}$ \\
\hline Aquadest & $0.00^{\mathrm{a}} \pm 0.00$ & Kuat \\
Jeruk nipis & $14.97^{\mathrm{b}} \pm 2.53$ & Kuat \\
Jeruk purut & $15.40^{\mathrm{b}} \pm 1.68$ & Kuat \\
Jeruk limau & $16.55^{\mathrm{b}} \pm 2.00$ & Kuat \\
\hline Notasi huruf yang berbeda menunjukkan adanya \\
perbedaan yang nyata $(\mathrm{p}<0.05)$
\end{tabular}

\section{Pembahasan}

Berdasarkan hasil uji mikrobiologi dengan menggunakan metode difusi agar menunjukkan bahwa minyak atsiri daun jeruk nipis, jeruk purut dan jeruk limau dapat menghambat pertumbuhan Escherichia coli yang ditandai dengan terbentuknya daerah atau zona bening di sekitar cakram. Ratarata diameter zona hambat dari minyak atsiri jeruk nipis adalah $14.97 \mathrm{~mm}$, jeruk purut sebesar 15.40 $\mathrm{mm}$ dan jeruk limau adalah $16.55 \mathrm{~mm}$. Beberapa peneliti telah menguji aktivitas minyak atsiri daun jeruk antara lain hasil penelitian dari melaporkan bahwa minyak atsiri daun jeruk purut memiliki aktivitas antibakteri terhadap E. Coli dengan nilai $\mathrm{KHM}$ dan $\mathrm{KBM} \leq 0.0625 \%$.

Aktivitas kerja minyak atsiri dalam menghambat pertumbuhan atau mematikan bakteri yaitu dengan cara mengganggu proses terbentuknya membran dan atau dinding sel, membran atau dinding sel tidak terbentuk atau terbentuk secara tidak sempurna (Ajizah, 2018). Senyawa aktif antibakteri dalam minyak atsiri daun jeruk nipis adalah senyawa golongan terpena (Rosyad, 2009). Aktifitas antibakteri terpena diduga melibatkan pemecahan membran sel bakteri oleh komponen-komponen lipofilik (Jenssen et al., 2006). Senyawa terpena bekerja dengan merusak porin (protein transmembran) pada bakteri sehingga pertumbuhan bakteri terhambat atau mati (Salni et al., 2011). Selanjutnya Pandey \& Kumar (2013), menambahkan bahwa rusaknya porin yang merupakan pintu keluar masuknya senyawa akan mengurangi permeabilitas dinding sel bakteri sehingga bakteri akan kekurangan nutrisi dan akan menyebabkan pertumbuhan bakteri terhambat atau mati. Menurut Loh et al. (2011), 
minyak atsiri daun jeruk purut juga termasuk golongan terpena yang terdiri atas monoterpen teroksigenasi dalam jumlah besar yaitu $86.15 \%$ dari total minyak atsiri. Komponen utamanya adalah $\beta$-sitronelal, monoterpen $(66.85 \%$ dari total minyak atsiri) yang diikuti oleh $\beta$-sitronelol, linalool dan sitronelol.

Berdasarkan hasil uji Duncan menunjukkan bahwa tidak terdapat perbedaan rata-rata diameter zona hambat antara minyak atsiri daun jeruk nipis, jeruk purut dan jeruk limau, hal ini dapat disebabkan karena ketiga jeruk nipis tersebut tergolong dalam genus yang sama yaitu genus citrus. Menurut Morales et al. (2003) aktivitas penghambatan dikategorikan sangat kuat jika diameter zona bening > 20-30 mm, kuat jika zona bening $>10-20 \mathrm{~mm}$, sedang jika diameter zona bening 5-10 $\mathrm{mm}$ dan lemah jika diameter zona bening $<5 \mathrm{~mm}$. Berdasarkan hasil penelitian rata-rata diameter zona bening/zona hambat minyak atsiri jeruk nipis adalah $14.97 \mathrm{~mm}$ (kategori kuat), begitu juga dengan minyak atsiri jeruk purut $(15.40 \mathrm{~mm})$ dan minyak atsiri jeruk limau $(16.55 \mathrm{~mm}$ ) yang termasuk dalam kategori kuat.

\section{Kesimpulan}

Minyak atsiri dari beberapa jeruk nipis secara signifikan dapat menghambat pertumbuhan Escherichia coli. Rata-rata diameter zona hambat yang terbentuk menunjukkan bahwa diameter zona hambat paling besar terbentuk pada perlakuan yang diberi minyak atsiri jeruk limau dan tidak berbeda nyata dengan minyak atsiri jeruk purut dan minyak atsiri jeruk nipis.

Saran, diharapkan dapat dilakukan penelitian selanjutnya tentang potensi minyak atsiri dari genus citrus terhadap bakteri maupun jamur yang lain. Selanjutnya, juga diharapkan dapat dilakukan penelitian tentang formulasi sediaan minyak atsiri daun jeruk.

\section{Deklarasi Konflik Kepentingan}

Penulis telah menyatakan bahwa pada artikel ini tidak ada maupun terdapat potensi konflik kepentingan baik dari penulis maupun instansi sehubungan dengan penelitian yang telah dilakukan, baik berdasarkan kepengarangan, maupun publikasi.

\section{Ucapan Terima Kasih}

Bagian kesempatan ini, kamu mengucapankan terima kasih kepada Direktur Politeknik Kesehatan Kemenkes Aceh atas bantuan dana penelitian, serta kepada Ketua Jurusan Farmasi yang telah membantu dan memberikan ijin kontribusi terhadap pelaksanaan penelitian. Selain itu, ucapan terima kasih juga kami sampaikan kepada Bapak pembimbing/ supervisor yang telah membantu perbaikan baik secara teknis maupun isi dalam pelaksanaan penelitian ini.

\section{Daftar Rujukan}

Ajizah, A. (2018). Sensitivitas Salmonella tyhimurium terhadap ekstrak daun Psidium guajava L. Bioscientiae, 1(1), 31-38.

Armando, R. (2009). Memproduksi 15 Minyak Atsiri Berkualitas. Penebar Swadaya Grup.

Chutia, M., Bhuyan, P. D., Pathak, M. G., Sarma, T. C., \& Boruah, P. (2009). Antifungal activity and chemical composition of Citrus reticulata Blanco essential oil against phytopathogens from North East India. LWT-Food Science and Technology, 42(3), 777-780.

Fadlilah, M. (2015). Benefit of Red Betel (Piper crocatum Ruiz \& Pav.) as Antibiotics. Jurnal Majority, 4(3), 71-75.

Grafton-Cardwell, E. E., Stelinski, L. L., \& Stansly, P. A. (2013). Biology and management of Asian citrus psyllid, vector of the huanglongbing pathogens. Annual Review of Entomology, 58, 413-432.

Hertiani, T., Palupi, I. S., Sanliferianti, \& Nurwindasari, H. D. (2003). Uji Potensi Antimikroba terhadap S. aureus, E. coli, Shigella dysentriae dan Candida albicans dari Beberapa Tanaman Obat Tradisional untuk Penyakit Infeksi. Pharmacon, 4(2).

Jawetz, E., Melnick, J., Adelberg, E., Brooks, G., Butel, J., \& Ornston, L. (2005). Mikrobiologi Kedokteran (Nugroho \& R. F. Maulany (eds.); Edisi ke-2). Penerbit Buku Kedokteran EGC.

Jenssen, H., Hamill, P., \& Hancock, R. E. W. (2006). Peptide antimicrobial agents. Clinical Microbiology Reviews, 19(3), 491-511.

Kan, Y., Uçan, U. S., Kartal, M., Altun, M. L., Aslan, S., Sayar, E., \& Ceyhan, T. (2006). GC-MS analysis and antibacterial activity of cultivated Satureja cuneifolia Ten. essential oil. Turkish Journal of Chemistry, 30(2), 253- 
259.

Kharismayanti, A. (2015). Uji Aktivitas Antibakteri Minyak Atsiri Daun Jeruk Nipis (Citrus aurantifolia (Christm. \& Panz.) Swingle) Terhadap Porphyromonas gingivalis ATCC 33277 Secara In Vitro [University of Jember]. In Faculty of Dentistry, https://repository.unej.ac.id/handle/123456 789/65611

Loh, F. S., Awang, R. M., Omar, D., \& Rahmani, M. (2011). Insecticidal properties of Citrus hystrix DC leaves essential oil against Spodoptera litura fabricius. Journal of Medicinal Plants Research, 5(16), 3739-3744.

Marsono, Y. (2008). Prospek pengembangan makanan fungsional. Jurnal Teknologi Pangan Dan Gizi, 7(1), 19-27.

Morales, G., Sierra, P., Mancilla, A., PAREDES, A., LOYOLA, L. A., GALLARDO, O., \& BORQUEZ, J. (2003). Secondary metabolites from four medicinal plants from northern Chile: antimicrobial activity and biotoxicity against Artemia salina. Journal of the Chilean Chemical Society, 48(2), 13-18.

Pandey, A. K., \& Kumar, S. (2013). Perspective on plant products as antimicrobial agents: A review. Pharmacologia, 4(7), 469-480.

Rosyad, P. G. Y. (2009). Formulasi Gel Obat Jerawat Minyak Atsiri Daun Jeruk Nipis (Citrus aurantifolia, Swingle) dan Uji Daya Antibakteri (Propionibacterium acne) Secara In Vitro [Universitas Muhammadiyah Surakarta]. In Universitas Muhammadiyah Surakarta. http://eprints.ums.ac.id/3378/

Salni, S., Marisa, H., \& Mukti, R. W. (2011). Isolasi senyawa antibakteri dari daun jengkol (Pithecolobium lobatum benth) dan penentuan nilai KHM-nya. Jurnal Penelitian Sains, 14(1), 38-41. https://doi.org/https://doi.org/10.36706/jps .v14i1.125

Widharto, W. (2019). Tanaman dalam Manuskrip Indonesia sebagai Bahan Rujukan Penemuan Obat Baru. Jumantara: Jurnal Manuskrip Nusantara, 2(2), 154-180.

Yuliani, R., Indrayudha, P., \& Rahmi, S. S. (2011). Aktivitas antibakteri minyak atsiri daun jeruk purut (Citrus hystrix) terhadap Staphylococcus aureus dan Escherichia coli. Pharmacon, 12(2), 101-110. 